\title{
Effects of Agro-ecological Practices on the Bio-functioning of Soil and Water Resources in the Rural Commune of Falwel (Dosso-Niger)
}

\author{
Djabri Hassimiou Halidou, Maman Manssour Abdou, Zoubeirou Alzouma Mayaki
}

\begin{abstract}
The decline in soil fertility, one of the main constraints of the agricultural sector in Niger, is still prevalent in several production areas where land is exploited every year without fallowing. Faced with this situation, various solutions such as the adoption of agroecological practices have been considered. In order to evaluate the level and constraints of adoption of these practices as well as their effects on the bio-functioning of soils and water resources, a study was conducted among 100 producers in the rural commune of Falwel. Soil samples were collected from the community sites and analyzed at the INRAN soil laboratory to assess the effect of reclaiming degraded land on soil fertility and vegetation cover improvement. The collected data were analyzed with Xlstat 2014 version 5.3 software. The results of the study showed that the practices of land restoration and promotion of ecological market gardening were adopted respectively by 35 and $64 \%$ of the producers surveyed because of their contribution to the improvement of soil fertility and their low-cost practice. On the other hand, the practice of over-digging surface water points was less adopted with an adoption rate of less than $20 \%$. The reasons cited include the difficulty of implementing it on an individual scale, the lack of equipment and the arduousness of the activities. Moreover, physicochemical analyses have shown that the practices have had various effects on the physicochemical characteristics of these soils and the expected effects are sometimes not immediately observable.
\end{abstract}

Index Terms - Contrainst, soil fertility, Productivity, water points, Niger.

\section{INTRODUCTION}

Soil fertility management and conservation practices can contribute to the improvement of food security and poverty reduction through better intensification of some agroecological practices [1]. Moreover, these practices allow producers to increase income and improve their food security system capable of meeting the demands of national as well as international markets [2]. However, land degradation associated with climate change, reduces the water retention capacity of soils and the resistance of crops to drought. The current majority practices are still those of the intensive conventional agricultural model, which has developed

Hassimiou Halidou DJABRI Sustainable Crop Production Department, Boubacar Bâ University of Tillabéri, BP 175 Tillabéri, Niger

Abdou MAMAN MANSOUR,Sustainable Crop Production Department, Boubacar Bâ University of Tillabéri, BP 175 Tillabéri, Niger

Alzouma Mayaki ZOUBEIROU, Department of Biology, Abdou Moumouni Universitty of Niamey, BP 10662 Niamey-Niger strongly over the past decades. This type of agriculture, in which organic inputs have been gradually replaced by synthetic fertilizers, has caused numerous problems for the fertility of agricultural land, particularly in terms of a drop in the level of organic matter, which has led to a high degree of sensitivity to erosion due to a loss of structural stability [3].

Faced with this situation, the challenge for agricultural research is enormous. It must increase the productivity and competitiveness of agriculture by improving crop yields, product quality while conserving the environment [4].

Indeed, good physico-chemical conditions (air and water circulation, temperature and $\mathrm{pH}$ ) will promote good biological activity which in turn will generate good soil structuring (formation of pores and aggregates in the soil, humification and mineralization of $\mathrm{OM}$ and thus release of nutrients for plants, etc.). We can then speak of a "virtuous circle of soil functioning" essential to the proper development of crops [5]. Soil fertility and its management represent a major issue for limiting climate change, as well as for maintaining sustainable agricultural production, even if current and majority agricultural practices do not currently take into account all the means to ensure this fertility in the future [6]. Breaking with the objectives of intensive conventional agriculture, the principles of agroecology suggest that the conduct of plant production should be based on "the constant improvement of soil fertility and biological activity while giving priority to the contribution of organic amendments. It is thus a matter of feeding the soil to feed the plant" [7-8].

Agriculture, the activity of which it is the support, can reverse, accelerate or even provoke evolutions in such a way that some of these evolutions can call into question the agricultural potential of the soil or, in other words, its fertility [9]. Indeed, due to the great diversity of crops and the intensification of production on a limited area, agricultural production often rhymes with intensive use of the soil through repeated tillage interventions and rapidly degraded organic fertilizer inputs [10]. These practices have often been justified by expected benefits on the quantity and quality of products but in the short and medium term, risks of decreasing soil fertility are conceivable [11]. However, at present, it is rather the efficiency of nutrient metamorphosis that is coming to the forefront as a measure of soil fertility [12], as we realize that this fertility is the result of the expression of biological, physical and chemical components of soils and their interactions that influence this nutrient cycle in particular [13]. Hence the importance of better knowledge of different endogenous land management practices in the context of agroecological sustainability for better agricultural 
productivity. Moreover, in recent years, few cultural practices generating better soil fertility management have been developed, with the exception of agroecological practices in particular [14]. Indeed, there are no ready-made answers but rather combinations of practices and actions to promote production practices and approaches that conserve soil and water resources [15]. It is in this perspective that the present study was initiated and aims at evaluating the effect of agroecological practices on soil and water bio-functioning in order to ensure food security of farm households.

\section{MATERIALS AND METHODS}

\subsection{Study site}

The study area is composed of four villages in the rural commune of Falwel. Figure 1 below shows the geographical location of the study sites.

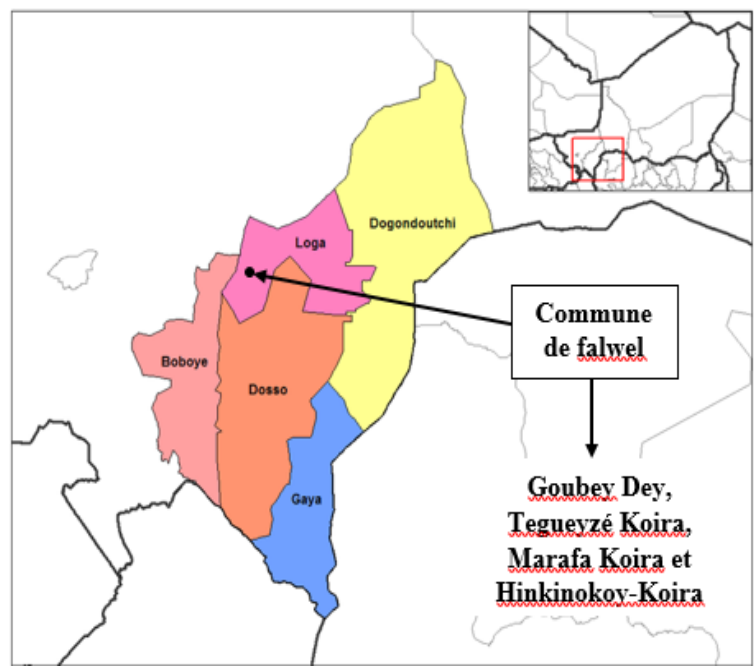

Fig. 1: Map of the geographical location of the study area

\subsection{Collection and analysis of soil samples}

In order to evaluate the effect of agroecological practices on the bio-functioning of soils and plant cover, soil samples were taken. A total of nine (9) soil samples were taken at a depth of $25 \mathrm{~cm}$ on three separate sites. The samples were sent to the soil laboratory of INRAN in Niamey for physico-chemical analysis. The physico-chemical parameters of the soils were determined according to AFNOR NF X31-130 standards.

\subsection{Field investigation}

To assess the level and constraints of agro-ecological practices adoption, a survey was conducted in December 2020 among 100 randomly selected producers in four villages of the commune of Falwel. This sample represents $37.59 \%$ of the beneficiaries of the emergency interventions. The survey unit was the head of the beneficiary household. The collection tool used was a structured interview guide. The information contained in this guide relates to the socio-economic characteristics of the farms (age, gender, level of education, etc.), as well as information on the effects of the practices on soil fertility, water resources and the constraints related to their use. Agroecological soil fertility and water resource management practices include:

- Restoration of degraded lands (CES/DRS) ;

- Over sinking of surface water points ;

- The promotion of home gardens.

\subsection{Data analysis and processing}

Descriptive statistics was used to characterize the effects of technologies on soil physicochemical characteristics and water resources availability. Discriminant and multivariate analyses were done with Xlstat-2014 version 5.3 software to identify the interrelationship between agroecological practices and soil and water resources bio-functioning. Pearson correlation matrix (n) was used to determine the correlation between soil fertility variables and associated factors.

\section{RESULTS}

\subsection{Agroecological practices and associated effects}

\section{$>$ Overburdening of water points}

Overflowing the water points is a long-term solution to the plight of the people in the area, particularly the conflicts between farmers and herders over access to water resources. Indeed, before the adoption of the project, the storage capacity and the duration of water conservation of these ponds were very limited because the ponds dried up after two months after the rainy season and the village ponds were the only water points that people and animals shared while waiting for the next season. Following the work of sinking these ponds, which has been doubly beneficial (local labour, works) to the beneficiaries, the storage capacity has increased by several thousand cubic metres and the duration of drying up has been extended by more than six months after the rainy season. In addition, the producers have all the time they need to harvest their agricultural products and collect the residues before the animals descend on the village watering holes. The water from these ponds is also used for other purposes, including the harvesting of late season legumes (voandzou and groundnuts) by moistening the compacted soil by pouring water around the root zone. The making of banco bricks and 
the drawing of water for the construction of houses are also done around semi-permanent ponds following interventions.

Fig 2 and 3 below illustrate respectively the ponds developed (Bangou Béri and Bangou Touganté).

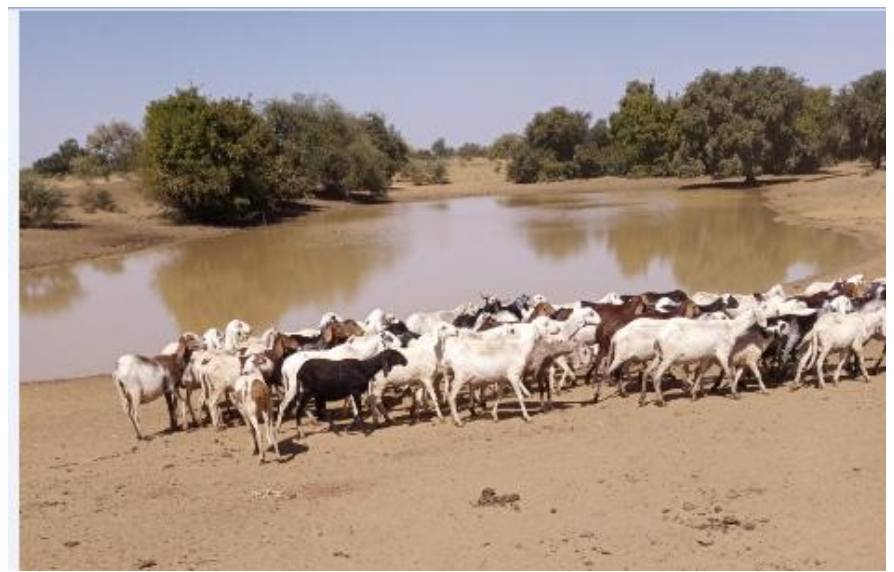

Fig. 2: Overview of the Bangou Beri pond (source author 05/12/2020)

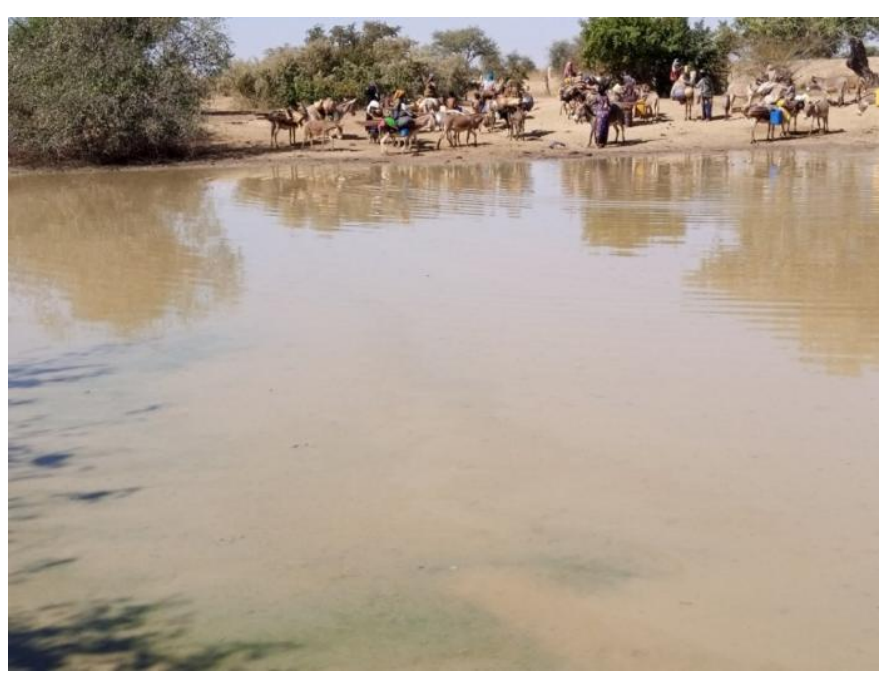

Fig. 3: Nomadic communities drawing water at the edge of the Bangou Touganté waterhole $(05 / 12 / 2020)$

\section{Restoration of degraded lands}

Reclamation of degraded land or glacis in crop fields is also highly valued among innovative soil fertility and water resource management practices. Indeed, the restoration of land and its development have contributed to the increase of soil fertility and the improvement of vegetation cover in the restored areas. Moreover, this intervention has allowed the expansion of the technique in the personal fields of all the beneficiaries and beyond to the entire population of the area. In addition, this work has greatly contributed to the reduction of rainwater runoff that was invading the dune fields and some residential areas. The increase in biological diversity, the creation of a microclimate in the area and the return of small fauna are other effects of the recovery of land on the ecosystems of the study area.

Fig 2 and 3 below illustrate respectively Community field rehabilitated by CES/DRS techniques and Construction of anti-erosion works (multifunctional half-moon) on a degraded site.

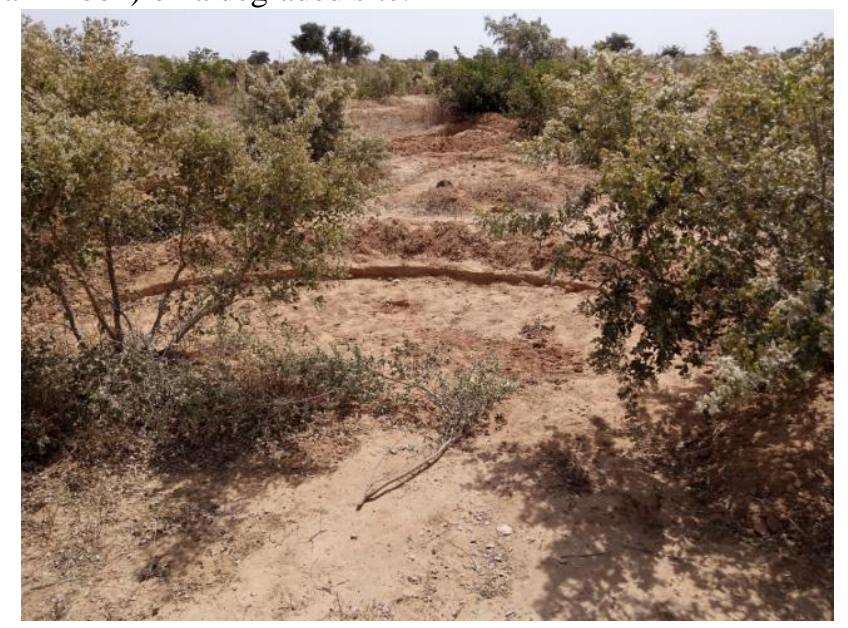

Fig. 4: Community field rehabilitated by CES/DRS techniques

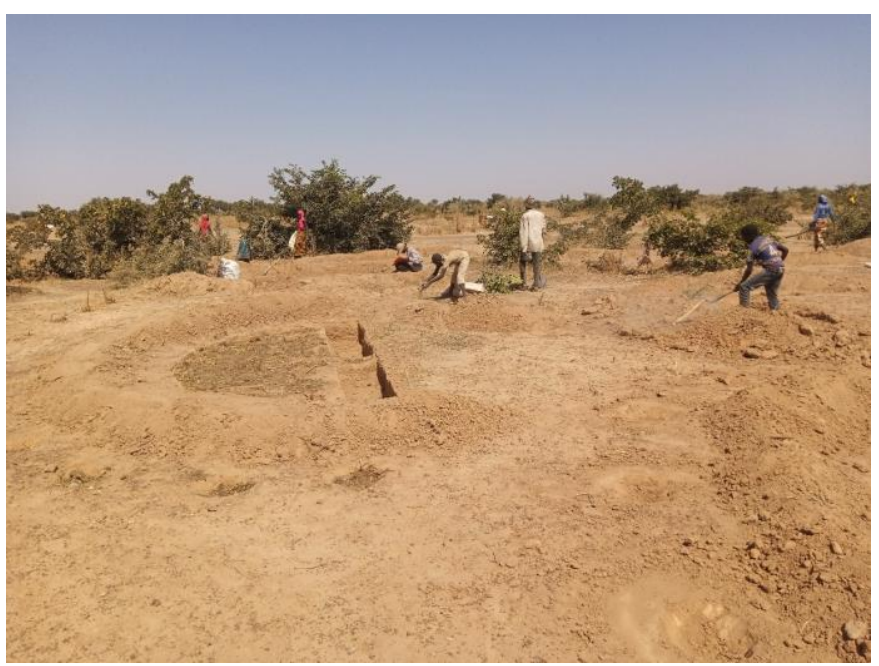

Fig. 5: Construction of anti-erosion works (multifunctional half-moon) on a degraded site

\section{$>$ Intensification of ecological vegetable gardening}

The promotion of home gardens is a very relevant resilient intervention in that it allows beneficiaries to be autonomous in feeding themselves without depending on external food aid. Indeed, market gardening constitutes an alternative to climatic constraints in favourable areas because it offers producers the opportunity to produce outside the wet season and to overcome climatic adversity. This contributes to the availability of agricultural products throughout the year and to better support the lean season. Producers with a substantial food stock can better tackle field work during the rainy season than those who have to ensure their daily life before thinking about field work through endless acrobatics throughout the 
Effects of Agro-ecological Practices on the Bio-functioning of Soil and Water Resources in the Rural Commune of Falwel (Dosso-Niger)

season while waiting for the new harvest. The photo below illustrate the home gardens in the village of Tegueyzé Koira zeno. Fig. 6 below illustrate the overview of a hut garden..

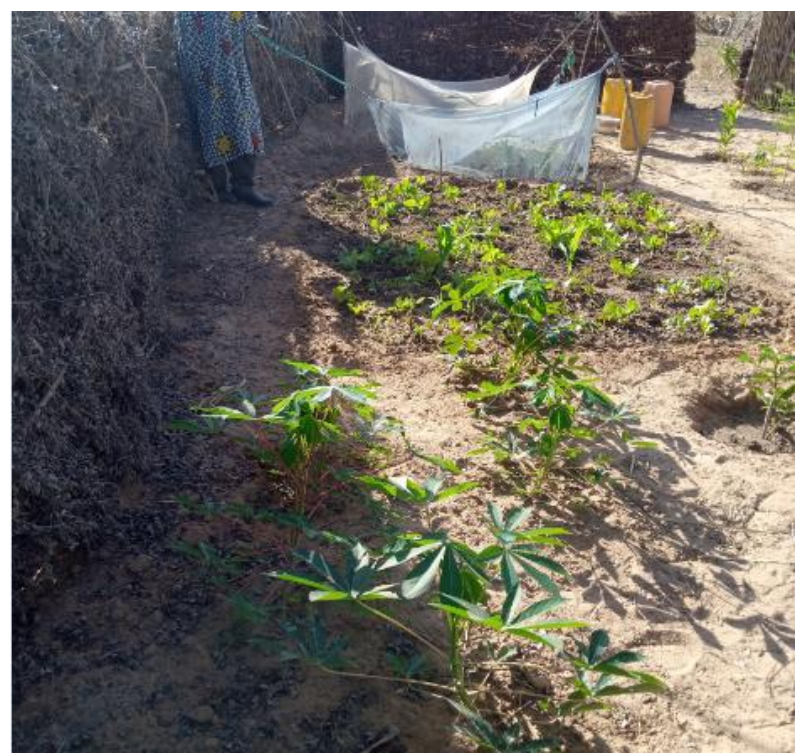

is adopted by $35 \%$ of the respondents. The development of water points is the least adopted practice of all (18\%). Several reasons were given to explain the low adoption rate. The respondents mentioned the lack of equipment (98\%). Indeed, this technology requires a lot of investment (12\%) and a certain technicality for its application. In addition, this technology can only be applied to large or small areas of water and requires a lot of time to implement.

The results show that hut gardening is adopted by $64 \%$ of producers. On the other hand, the restoration of degraded land

Fig.6: Overview of a hut garden in Tegueyzé Koira Zeno (05/12/2020)

\subsection{Level and constraints of adoption of agroecological} practices

The level of adoption of agroecological practices is presented in Table 1

Table 1 : Adoption level of agro ecological practices

\begin{tabular}{lcccc}
\hline AE Practices & Adoption & WOMAN & MAN & Total \\
\hline \multicolumn{1}{c}{ Restoration of degraded } & NOT & 35 & 30 & 65 \\
\multicolumn{1}{c}{ lands (CES/DRS) } & YES & 14 & 21 & 35 \\
Development of water & NOT & 37 & 45 & 82 \\
points & YES & 3 & 15 & 18 \\
Promotion of home gardens & NOT & 3 & 33 & 36 \\
& YES & 47 & 17 & 64
\end{tabular}

AE: Agroecology

3.3. Effects of AE practices on the physico-chemical characteristics of soils

Physical characteristics of soils

\begin{tabular}{ccccccc}
\hline Num Ech. & Site & $\begin{array}{c}\text { Depth } \\
(\mathbf{c m})\end{array}$ & $\begin{array}{c}\text { Clay } \\
(\boldsymbol{\%})\end{array}$ & $\begin{array}{c}\text { Silt } \\
(\boldsymbol{\%})\end{array}$ & $\begin{array}{c}\text { Fine Sand } \\
(\boldsymbol{\%})\end{array}$ & $\begin{array}{c}\text { Coarse } \\
\text { Sand }(\boldsymbol{\%})\end{array}$ \\
\hline $\mathbf{1}$ & Goubey D & $0-25 \mathrm{~cm}$ & 15.92 & 10.61 & 30.26 & 43.21 \\
$\mathbf{2}$ & Goubey D & $0-25 \mathrm{~cm}$ & 8.89 & 1.21 & 35.75 & 54.29 \\
$\mathbf{3}$ & Goubey D & $0-25 \mathrm{~cm}$ & 15.71 & 0.70 & 29.01 & 54.58 \\
\hline
\end{tabular}




\begin{tabular}{lllllll}
\hline $\mathbf{4}$ & Marafa K & $0-25 \mathrm{~cm}$ & 23.37 & 7.68 & 43.85 & 25.10 \\
$\mathbf{5}$ & Marafa K & $0-25 \mathrm{~cm}$ & 19.99 & 5.10 & 34.12 & 40.78 \\
$\mathbf{6}$ & Marafa K & $0-25 \mathrm{~cm}$ & 29.18 & 5.85 & 31.12 & 33.85 \\
$\mathbf{7}$ & Tegueyzé K & $0-25 \mathrm{~cm}$ & 13.84 & 21.62 & 27.84 & 36.70 \\
$\mathbf{8}$ & Tegueyzé K & $0-25 \mathrm{~cm}$ & 25.91 & 3.23 & 28.86 & 42.00 \\
$\mathbf{9}$ & Tegueyzé K & $0-25 \mathrm{~cm}$ & 22.72 & 8.95 & 37.77 & 30.56 \\
\hline
\end{tabular}

by the Agronomic laboratory of Normandy on the basis of the percentages in clay and silt makes it possible to note the

The results of the physical analysis of the soil are presented in Table 2.

The results of the granulometric analyses show a dominance of the sandy texture on the whole of the samples with a strong tendency towards coarse sand except for the first sample of the site of Marafa Koira where the sandy proportion is largely dominated by the fine sand fraction $(43,85 \%)$. As for the clay content, the control sample of Marafa Koira presents the best content with a rate of $29.18 \%$ against respectively $25.91 \%$ for Tegueyzé Koira 2, 23.37\% in Marafa Koira 1. The lowest clay rate $(8.89 \%)$ was observed in the sample 2 of Goubey Day The silty fraction presents slightly variable contents with extremes of $0.70 \%$ and $21.62 \%$. The determination of the texture of the soils according to the textural triangle proposed following respective textures :

Goubey Day 1: Clayey sand ( $\mathrm{L}=10,61 \%, \mathrm{~A}=15,92 \%)$, Goubey Day 2: Pure sand ( $\mathrm{L}=1,21 \%, \mathrm{~A}=8,89 \%)$, Goubey Day temoin: Clayey sand $(\mathrm{L}=15,71 \%, \mathrm{~A}=0,72 \%)$, Marafa koira 1: Clayey sand ( $\mathrm{L}=7,68 \%, \mathrm{~A}=23,37 \%)$, Marafa Koira 2 : Clayey sand ( $\mathrm{L}=5.10 \%, \mathrm{~A}=19.99 \%)$, Marafa Koira temoin: Very sandy clay $(\mathrm{L}=5.85 \%, \mathrm{~A}=29.18 \%)$, Tegueyzé Koira 1 : Sand ( $\mathrm{L}=21.62 \%, \mathrm{~A}=13.84 \%)$, Tegueyzé Koira 2: sandy clay $(\mathrm{L}=3.25 \%, \mathrm{~A}=25.9 \%)$ and Tegueyzé Koira control: clayey sand $(\mathrm{L}=8.95 \%, \mathrm{~A}=22.72 \%)$.

\section{Chemical characteristics of soils}

a) Descriptive statistics

Table 2: Descriptive statistics of soil physico-chemical caracteristics

\begin{tabular}{ccccc}
\hline Variable & Minimum & Maximum & Average & $\begin{array}{c}\text { Standard } \\
\text { deviation }\end{array}$ \\
\hline pH & 3,6300 & 5,3200 & 4,5200 & 0,5037 \\
CE & 0,0200 & 0,0800 & 0,0322 & 0,0192 \\
CA++ & 2,9000 & 6,5000 & 4,8056 & 1,2778 \\
Mg++ & 0,2540 & 0,7710 & 0,4582 & 0,1569 \\
Na+ & 0,0960 & 0,1470 & 0,1223 & 0,0194 \\
K+ & 0,0870 & 0,3080 & 0,1667 & 0,0796 \\
CEC & 3,9300 & 7,1200 & 5,7611 & 1,1721 \\
AE & 0,0000 & 0,5290 & 0,2091 & 0,2179 \\
P_ass & 3,8100 & 7,6900 & 6,1478 & 1,5020 \\
Carb. & 0,0700 & 0,2600 & 0,1622 & 0,0696 \\
Azote & 0,0180 & 0,0530 & 0,0298 & 0,0123 \\
C/N & 3,0000 & 13,0000 & 6,4444 & 3,1667 \\
M.O & 0,1200 & 0,4400 & 0,2767 & 0,1162 \\
\hline
\end{tabular}

From this table (2), it can be seen that all the samples analysed have a very acidic $\mathrm{pH}$ with an average of $4.52(\leq 5.5)$ and a standard deviation of 0.5237 . The agricultural soils have a $\mathrm{pH}$ between 4 and 9 , with rare exceptions. The $\mathrm{pH}$ value is subject to seasonal variations depending on the water status of the soil, its temperature, the presence or not of a crop in active growth period. Electrical conductivity varies slightly (0.0322 on average). As for the exchangeable bases, they present low values except for $\mathrm{CA}^{++}$, whose content is more or 
less appreciable compared to $\mathrm{Mg}^{++}, \mathrm{Na}^{+}$and $\mathrm{K}^{+}$with an average of $4.80 \mathrm{meq} / 100 \mathrm{~g}$.

\section{b) Correlation between variables and factors}

The distribution of these different variables according to thesites is highlighted by a principal component analysis in which the first two axes explain $58.26 \%$ of the total variance . (fig7).

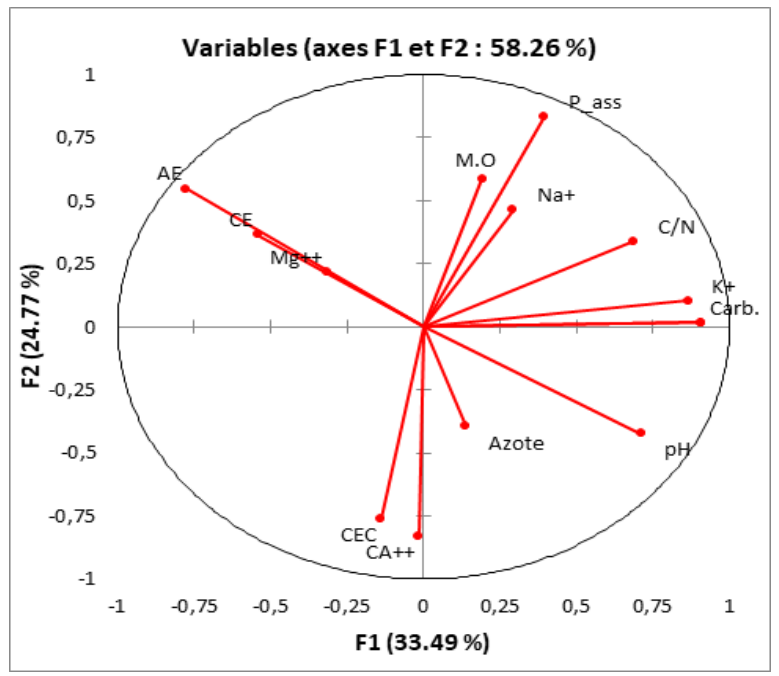

Fig.7: Principal component analysis of soil chemical characteristics

The F1 axis contributes to $33.49 \%$ of the total inertia of the variables against $24.77 \%$ of the total inertia for the F2 axis. The F1 axis carries on its positive part the variables : Organic matter (0.909), total carbon (0.907), $\mathrm{C} / \mathrm{N}$ ratio (0.688), potassium (0.863), sodium (0.291), assimilable phosphorus (0.393), magnesium (-0.315), electrical conductivity $(-0,541)$ and exchange acidity $(-0.775)$ which are respectively opposed to $\mathrm{pH}(0.711)$, calcium $(-0.014)$, cation exchange capacity $(-0.138)$ and total nitrogen $(0.139)$ carried by the negative part of the F1 axis. The same distribution of variables can be observed on the F2 axis, which also isolates the variables with a low contribution to the total inertia $\left(\mathrm{CEC}, \mathrm{Ca}^{++}, \mathrm{EC}\right.$, $\mathrm{AE}$ and $\mathrm{Mg}^{++}$) compared to the other variables. It is therefore an axis of good soil condition. It thus opposes the soil fertility parameters on its positive part to the structuring and consistency parameters on its negative part Axis 1 is an axis of expression of the different variables according to the agroecological practices. It therefore highlights the behaviour of each parameter under different treatments.

\section{c) Variables contribution}

The figure below shows the contribution of the variables to the total variance.

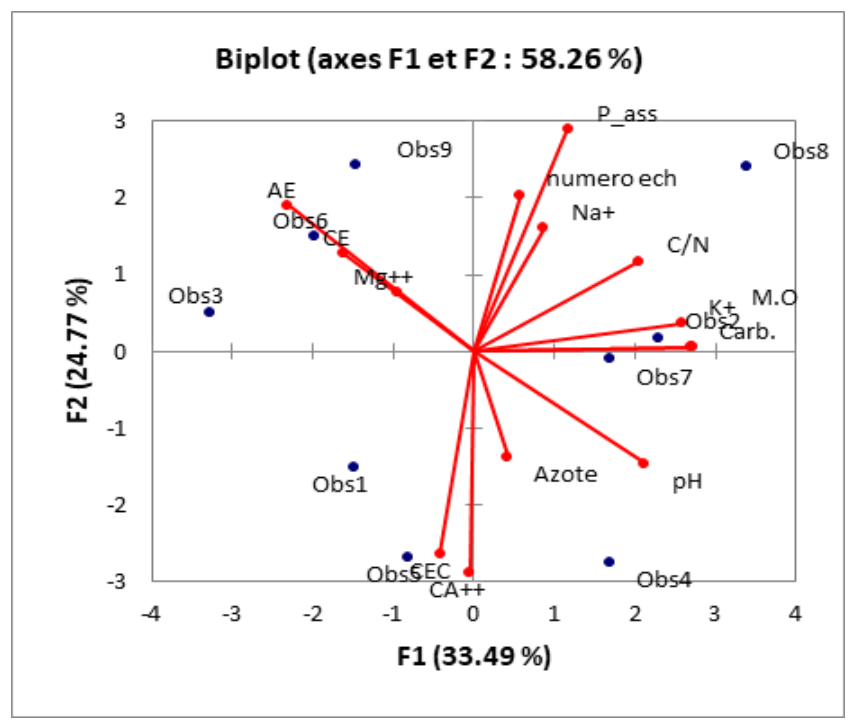

Fig. 8: Biplot_contribution of variables

Discriminant analysis grouped the different observations according to their similarities, as determined by the responses of fertility level and soil structure (figure 2). From this figure, it appears that the principal components ( $\mathrm{CP} 1$ and $\mathrm{CP} 2)$ contributed at $58.26 \%$ of the variance. Based on the correlations between variables and factors, total nitrogen; organic matter, potassium, $\mathrm{C} / \mathrm{N}$ ratio, sodium, assimilable phosphorus, calcium and CEC are associated with observations 2, 4.8 and 5 for the formation of axis 1. $\mathrm{pH}$, total carbon, magnesium, electrical conductivity, and exchange acidity, participate with observations $1,3,7$ and 9 in the formation of axis 2. This separation shows that most of the variables were similar for all observations. The CP1 axis presents the overall result on the different variables. Indeed, the score or coordinate of these observations on the CP1 axis follows the same ranking as that of the overall average of each parameter on all observations. Moreover, the highest observation on the graph (obs8) with the highest coordinate on the $\mathrm{CP} 2$ axis comes from soil restoration as an agroecological practice, the results of which are more contrasted, unlike observation 4 . This graph also shows that observations 2 and 7 have a score close to 0 on the CP2 axis because they have very homogeneous values for all the variables (pH, EC, AE, CEC, $\mathrm{Na}+\mathrm{K}+, \mathrm{Mg}++, \mathrm{Ca}++, \mathrm{C}, \mathrm{N}$, $\mathrm{C} / \mathrm{N}, \mathrm{Mo}$ ) but at different levels. The $\mathrm{CP} 2$ axis thus contrasts the level of fertility with the soil structure.

\section{d) Pearson correlation matrix (n)}

The results of Pearson correlation between parameters and observations are presented in the table 4. 
The analysis of the table 4 shows a correlation between the different variables. Thus, a positive correlation was observed between $\mathrm{pH}$ and potassium $(\mathrm{K}+)$, electrical conductivity $(\mathrm{EC})$ and exchange acidity (EA) respectively. On the other hand, a significant negative correlation was observed between $\mathrm{pH}$ and exchange acidity (-0.9073) Exchangeable bases are correlated with cation exchange capacity (0.9797), assimilable phosphorus (0.7632), $\mathrm{C} / \mathrm{N}$ ratio (0.7428), exchange acidity (-0.7024), total carbon (0.6748), organic matter (0.6786), respectively. Organic matter is strongly correlated with total carbon and $\mathrm{C} / \mathrm{N}$ ratio.

\section{DISCUSSION}

The results on the level and constraints of adoption of agroecological practices showed that the restoration of degraded lands and the intensification of ecological market

Table 4: Correlation matrix between variables

\begin{tabular}{|c|c|c|c|c|c|c|c|c|c|c|c|c|c|}
\hline Variables & pH & $\mathbf{C E}$ & $\mathrm{CA}++$ & Mg++ & $\mathrm{Na}+$ & $\mathbf{K}+$ & CEC & $\mathbf{A E}$ & P_ass & Carb. & Azote & $\mathbf{C} / \mathbf{N}$ & M.O \\
\hline $\mathbf{p H}$ & 1 & $-0,7450^{*}$ & 0,1430 & $-0,2318$ & $-0,0838$ & $0,5926^{*}$ & $-0,0050$ & $-0,9073^{*}$ & $-0,0759$ & 0,4511 & 0,0538 & 0,3096 & 0,4533 \\
\hline CE & $-0,7450$ & 1 & $-0,0744$ & $-0,1821$ & 0,1084 & $-0,4555$ & $-0,0096$ & $0,6705^{*}$ & 0,0556 & $-0,3405$ & $-0,4092$ & 0,0228 & $-0,3433$ \\
\hline $\mathrm{CA}++$ & 0,1430 & $-0,0744$ & 1 & $-0,3083$ & $-0,1239$ & $-0,0415$ & $0,9797^{* *}$ & $-0,3466$ & $-0,6007^{*}$ & 0,0589 & 0,3421 & $-0,3420$ & 0,0700 \\
\hline Mg++ & $-0,2318$ & $-0,1821$ & $-0,3083$ & 1 & $-0,3674$ & 0,0055 & $-0,1599$ & 0,2595 & 0,0757 & $-0,3765$ & $-0,2361$ & $-0,2319$ & $-0,3825$ \\
\hline $\mathrm{Na}+$ & $-0,0838$ & 0,1084 & $-0,1239$ & $-0,3674$ & 1 & 0,1231 & $-0,1195$ & 0,2191 & $0,7632^{*}$ & 0,3717 & 0,2461 & 0,0176 & 0,3873 \\
\hline $\mathbf{K}+$ & 0,5926 & $-0,4555$ & $-0,0415$ & 0,0055 & 0,1231 & 1 & $-0,1041$ & $-0,7024$ & 0,3930 & 0,6748 & $-0,2384$ & $0,7428^{*}$ & $0,6786^{*}$ \\
\hline CEC & $-0,0050$ & $-0,0096$ & 0,9797 & $-0,1599$ & $-0,1195$ & $-0,1041$ & 1 & $-0,2019$ & $-0,5654$ & $-0,0431$ & 0,3118 & $-0,4359$ & $-0,0311$ \\
\hline $\mathbf{A E}$ & $-0,9073$ & 0,6705 & $-0,3466$ & 0,2595 & 0,2191 & $-0,7024^{*}$ & $-0,2019$ & 1 & 0,2165 & $-0,5902^{*}$ & $-0,0905$ & $-0,4535$ & $-0,5893^{*}$ \\
\hline$P_{-}$ass & $-0,0759$ & 0,0556 & $-0,6007$ & 0,0757 & 0,7632 & 0,3930 & $-0,5654^{*}$ & 0,2165 & 1 & 0,4015 & $-0,1365$ & 0,3569 & 0,4084 \\
\hline Carb. & 0,4511 & $-0,3405$ & 0,0589 & $-0,3765$ & 0,3717 & 0,6748 & $-0,0431$ & $-0,5902$ & 0,4015 & 1 & 0,3518 & $0,6018^{*}$ & $0,9995^{* *}$ \\
\hline Azote & 0,0538 & $-0,4092$ & 0,3421 & $-0,2361$ & 0,2461 & $-0,2384$ & 0,3118 & $-0,0905$ & $-0,1365$ & 0,3518 & 1 & $-0,4167$ & 0,3529 \\
\hline $\mathrm{C} / \mathrm{N}$ & 0,3096 & 0,0228 & $-0,3420$ & $-0,2319$ & 0,0176 & 0,7428 & $-0,4359$ & $-0,4535$ & 0,3569 & 0,6018 & $-0,4167$ & 1 & $0,5923^{*}$ \\
\hline M.O & 0,4533 & $-0,3433$ & 0,0700 & $-0,3825$ & 0,3873 & 0,6786 & $-0,0311$ & $-0,5893$ & 0,4084 & $\begin{array}{r}0,9995 \\
0,3529 \\
\end{array}$ & & 0,5923 & 1 \\
\hline
\end{tabular}

Indeed, in crop production fertility management is crucial in that agronomically, fertility is a quantitative measure related to the richness of the soil in mineral elements and its management is particularly important as its maintenance is necessary for the sustainability of organic systems [16-17].

In Niger, farmers adapt certain practices such as crop association, soil fertility management practices and tillage to the surface variability of the soil in their fields. These different processes are responsible for the interest in farmers' management of trees and shrubs such as assisted natural regeneration (ANR) and, more broadly, agroforestry practices for land rehabilitation, combating soil depletion and improving crop production [18-19]. The low rate of adoption of water point over-digging can be explained by the fact that gardening through home gardens were adopted by more than $49 \%$. This is due to the decline in soil fertility caused by overexploitation and low levels of organic amendment. The improvement of soil fertility through the adoption of agroecological practices has become a necessity without which the producer would not get good yields due to the high pressure on arable land and lack of fallow land [4]. this technology is labour intensive which requires its practical application and is only applied periodically. The extension of this technology will require capacity building of the farmers so that they can take ownership of the technology. If producers do not adopt the technology sufficiently, it is partly due to lack of information [4]. Indeed, the lack of available information on the performance of innovative cropping systems leads farmers to evaluate these systems based on their experience and knowledge [20]. Thus, a better knowledge of biotic and abiotic properties of soils and their interactions is essential for the development of agroecological practices that aim both to deliver quality agricultural products in sufficient quantity and environmental services [21]. The results of the particle size analysis showed 
that these soils are predominantly sandy in texture with a predominance of coarse sand. Soil texture affects other soil properties, such as water availability, nutrient supply, and to some extent $\mathrm{pH}$ values, which in turn determine microbial growth and activity [22-23-24].

The cation exchange capacity of the soil represents the size of the reservoir allowing the reversible storage of certain cationic fertilising elements (potassium, magnesium, calcium, etc.). The CEC is linked to the clay-humus complex. The value of the CEC of a soil is therefore a function of the quantities of clay and OM it contains, but also of the nature of these elements and the $\mathrm{pH}$ of the soil. Thus, a soil with a clay content of $20 \%$ may very well have a lower CEC than a soil with a clay content of $15 \%$, depending on different geological supports, pedoclimatic past and development mode [25].

In this study, the results show that the CEC is very low (5.76 on average), which can be explained by the fact that these soils are relatively poor in clay and organic matter at the beginning. However, the restoration work carried out on these sites could contribute to a significant improvement in the organic matter content and therefore the fertility of the soil. Indeed, the reduction of surface runoff, the stabilization of the soil by the root system of young tree shoots contribute to the improvement of the soil surface condition [15]. Since, CEC varies greatly, especially in a $\mathrm{pH}$ range from 5.5 to 7.0 , the capacity of the soil to retain alkali and alkaline earth cations $\left(\mathrm{Ca}^{++}, \mathrm{Mg}^{++}, \mathrm{K}^{+}\right.$, in particular) is higher the closer the $\mathrm{pH}$ is to neutrality ( $\mathrm{pH} 7.0$ ), and vice versa [26]. Moreover, the variation of the surface electric charge (CEC) until its cancellation is at the origin of hydrophobic properties, especially at low $\mathrm{pHs}$, for organic materials used for example in horticultural substrates [27].

The results of the chemical analyses (Table 2) show that these soils have highly variable organic matter levels. This proves that the clay-humus complex of these soils is highly appreciable in the sense that the samples present a clay content varying from $8.89 \%$ to $29.18 \%$. Organic matter and clay content are closely related in that an organic matter content between 20 and $30 \%$ and a clay content between 22 and $30 \%$ indicate a soil with moderate organic matter. In addition, a clay content of less than $22 \%$ and an organic matter content of between 30 and $40 \%$ indicate that the soil is well supplied with organic matter [25]. Stable soil organic matter (humus) is derived from the gradual decomposition of crop residues, plants, animals and other biological organisms living in the soil (mites, fungi, microfauna, microflora...). Thus, the organic matter content of these soils varies from 3 to $13 \%$ and this variation reflects the low carbon and nitrogen contents. Moreover, microbial activity favours water infiltration and also plays an important role in the recycling and decomposition of plant residues; this leads to an increase in the organic matter, nitrogen, phosphorus and potassium content of soils [28-29]. As for the exchangeable bases, they present more or less appreciable values. Calcium plays a decisive role in the physical (stability of soil structures, sensitivity to slaking, gas and water exchanges, etc.), chemical (functioning of the CEC, desalination, etc.) and biological (activity of the microbial biomass, etc.) fertilities of the soil. The $\mathrm{C} / \mathrm{N}$ ratio is an essential factor in the dynamics of carbon and nitrogen. This $\mathrm{C} / \mathrm{N}$ ratio provides useful information on the evolution of soil organic matter [30], and is an indicator that allows us to judge the degree of evolution of organic matter, i.e. its ability to decompose more or less rapidly in the soil [31]. In this study, the average $\mathrm{C} / \mathrm{N}$ ratio is (6.44\%), a low value; which therefore reflects very favorable conditions of strong mineralization of organic matter following a good biological activity in the soil [32]. Variations in soil properties and yields in agricultural plots are often attributed to differences in topography and microtopography [33-34]. Application of organic manure in constrained areas is the main strategy against soil crusting and declining soil fertility. [35], showed that organic manure application is the most effective solution to maintain fertility and sustainability of production systems on all soil types in West Africa.

\section{CONCLUSION}

The study analysed the constraints related to the adoption of some soil and water management and conservation practices and their effects on the physicochemical properties of the soil. The lack of information and equipment on agroecological practices leads producers to poor application of these technologies such as ecological market gardening, which does not require a large workforce. On the other hand, practices such as the over-digging of water points and the 
reclamation of land require not only a large workforce but also, and above all, a certain technical skill for their implementation. These elements have contributed to the low level of adoption of these practices. The over-digging of water points, although not widely adopted, remains one of the most beneficial agro-ecological practices in that it increases water storage and conservation capacity, allows production activities (vegetable gardening, aquaculture) to be carried out around water points after the winter season, and reduces conflicts over access to water. The low level of popularization of these practices is a hindrance to their large-scale adoption.

\section{ACKNOWLEDGMENT}

The authors would like to thank sincerely the World Food Program/Niger (WFP) for his contribution to the data collection concerning this study.

\section{REFERENCES}

[1] Innocent Adédédji LABIY, Hamadé SIGUE, Do Christophe OUATTARA, Oumarou Mahamane TRAORE et Djibrillou KOURA. Effet des pratiques innovantes endogènes de gestion durable des terres sur la performance technico-économique du réseau de producteurs dans la commune de Mani au Burkina Faso, 2019. Afrique SCIENCE 15(1) $432-447$;

[2] S. J. P. ZOUNDOU, Etude des performances technico-économiques des entreprises agricoles au Burkina Faso : cas de celles formées en conseil de gestion à l'exploitation agricole dans la province du houet, Centre Agricole Polyvalent de Matourko, Burkina Faso, mémoire de fin de cycle en vue de l'obtention du diplôme de Conseiller d'Agriculture, (2014) 105 p.

[3] Robert, M. et Stengel, P. Sols et Agriculture : ressource en sol, qualité et processus de dégradation. Une prospective mondiale, européenne et française, 1999. Cahiers d'Agricultures, vol. 8, pp. 301-308;

[4] SANOU K., SOULE B. A. Contraintes d'adoption des technologies de gestion de la fertilité des sols en riziculture irriguée au sud du Togo, 2017. Agronomie Africaine 29 (2) : 177 - 184 ;

[5] GAB44, Guide de gestion de la fertilisation en marâ̂chage biologique, 2018. 63p ;.

[6] Vincent Le Cam. Gestion durable de la fertilité des sols : étude des pratiques innovantes des maraîchers biologiques diversifiés du Grand Ouest, 2019. Sciences du Vivant [q-bio]. ffdumas-02345474 ;

[7] Rey F., Coulombel A., Melliand M.-L., Jonis M. et Leclerc B., Produire des légumes biologiques, 2015 : guide technique. Éditions ITAB, Paris, $529 \mathrm{p}$;

[8] FAO, Les sols sont en danger mais la dégradation n'est pas irréversible, 2015. [En ligne]. [consulté le 6 septembre 2021] http://www.fao.org/news/story/fr/item/357221/icode/

[9] Doré T., Réchauchère O. et Schmidely P., Les clés des champs : l'agriculture en question, 2008. Éditions Quae, Versailles, 192p ;

[10] Projet SEFerSol, Dossier de presse. Lancement du projet SEFerSol Maraîchage biologique en Alsace, 2015. [En ligne]. [consulté le 03 septembre 2021]

http://www.opaba.org/bioenalsace/wp_content/uploads/2016/01/SEFe rSol_dossier.de_.presse_ao\%C3\%BBt2015vf.pdf. ;

[11] Thibaut C. et Lecompte F., Gestion de la fertilité des sols en cultures légumières et maraîchères, 2018. Rapport d'étude du GIS Piclég.72p. [En ligne] [consulté le 06/09/21].
https://www.picleg.fr/content/download/3887/37442/version/1/file/PI CLEG\%20-\%20Fertilit\%C3\%A9\%20des\%20sols\%20cultures\%201\% C3\%A9gumi\%C3\%A8res\%20-\%20Rapport.pdf ;

[12] Berner A. et al., Les principes de la fertilité des sols. Construire sa relation avec le sol, 2013. FiBL/Bio Suisse. 32p. [en ligne]. [Consulté le 20/07/21]. Disponible à l'adresse https://shop.fibl.org/chfr/mwdownloads/download/link/id/572/;

[13] Recous S., Chabbi A., Vertes F., Thiebeau T., Chenu C, La fertilité des sols : quels sont ses déterminants ? Quels approches et outils pour la qualifier, 2015. In Fourrages, vol 223, pp.189-196 ;

[14] Chitrit J-J., Gautronneau Y., Pratiques agricoles et fertilité des sols en France, 2011. In Revue Science Eaux \& Territoires [en ligne]. 01/2010, article hors-série, 8 p. [consulté le 28 août 2021]. http://www.setrevue.fr/pratiques-agricoles-et-fertilite-des-sols-en-fran ce\#article-citation ;

[15] AGRIDAPE, Revue sur l'agriculture durable à faible apport externes ; sols durables 2015. $\mathrm{N}^{\circ} 31$ volumes $1,36 \mathrm{P}$;

[16] Cadellon A. Fertilité des sols, la gérer maintenant pour mieux produire demain, 2014. AlterAgri novembre-décembre. 12 p.

[17] Saidou A., K. D. Gnakpenou, I. Balogoun, S. R. Hounnahi, M. V. Kindomihou. Effet de l'urée et du NPK 15-15-15 perlés et super granulés sur la productivité des variétés de riz IR841 et NERICA-L14 en zone de bas-fond au Sud-Bénin, 2014. Journal of Applied Biosciences, 77 : 6575 - 6589 ;

[18] Abdou M. M., Mayaki Z. A., Lamso N. D., Seybou D. E. et Ambouta J. M. K. - Productivité de la culture du sorgho (Sorghum bicolor) dans un système agroforestier à base d'Acacia senegal (L.) Willd. au Niger, 2014. Journal of Applied Biosciences, 82 (1), 7339-7346 ;

[19] Dan Lamso N., Guero Y., Dan-Badjo A. T., Lamar R., Bationo B. A., Djamen P. et Ambouta J.M.K., - Effet des touffes de Hyphaene thebaica (Mart) sur la production du mil dans la région de Maradi (Niger), 2015c. International Journal of Biological and Chemical Sciences, 9 (5), 2477-2487;

[20] Roussy C., A. Ridier, K. Chaib. Adoption d'innovations par les agriculteurs : rôle des perceptions et des préférences, 2015. Working Paper SMART - LERECO N¹5 - 03, INRA, Agro Campus Ouest, 37 $\mathrm{p}$;

[21] Claire Chenu, Naoise Nunan, Laure Vieublé, Patricia Garnier, Valérie Pot, Sylvie Recous. Localisation des matières organiques et des activités microbiennes : conséquences pour le fonctionnement du sol, colloque sur les sols et la vie souterraine, 2017. Éditions le quae, collection synthèse, $11 \mathrm{P}$;

[22] Ladd J.N., Foster R.C., Nannipieri P., \& Oades M.J. Soil structure and biological activity, 1996. In: Bollag, J.M., Stotzky, G.(Eds.), Dekker, New York, Soil Biochem. 9: 23-77 ;

[23] Görres J.H., Dichiaro M.J., Lyons J.B., \& Amador J.A. Spatial and temporal patterns of soil biological activity in a forest and an old field, 1998. Soil Biol. Biochem. $30: 219-230$;

[24] Leirós M.C., Trasar-Cepeda C., Seoane S., \& Gil-Sotres F. Biochemical properties of acid soils under climax vegetation (Atlantic oakwood) in an area of the European temperate humid zone (Galicia, NW Spain): general parameters, 2000. Soil Biol. Biochem. 32: 733-745 ; 
[25] LANO, Laboratoire Agronomique de Normandie, granulometrie des sols, 2020, 35p.

[26] Ary Bruand et Daniel Tessier, Le sol habitat : environnement physicochimique et conditions de développement des différents organismes présents dans le sol, acte de colloque sur Les sols et la vie souterraine, 2017. Editions Quae - Collection Synthèses, 10P ;

[27] Michel J.Ch., Influence of clay addition on physical properties and wettability of peatgrowing media, 2009. HortScience, 44(6), 1694-1697 ;

[28] Farji-Brener A. G. and Werenkraut V. - The effects of ant nests on soil fertility and plant performance : a meta-analysis, 2017. Journal of Animal Ecology, 86 (4), 866-877 ;

[29] B. Seyni Bodo X. Morvan, O. Malam Issa, D. Tidjani Adamou, J.-M. Ambouta Karimou, B. Marin, M. Ponthieu et G. Fronteau, Connaissance locale de la variabilité de surface du sol et des contraintes associées pour la production du niébé en zone sahélienne du Niger, Etude et Gestion des Sols, 2019. 26, 65-79;

[30] Gagnard J., Huguet C., \& Ryser J.P. L'analyse du sol et du végétal dans la conduite de la fertilisation, le contrôle de la qualité des fruits. Secrétariat générale OILB/SROP, 1988. Edition - Diffusion ACTA 87 $\mathrm{p}$;

[31] Giroux M., \& Audesse P.. Comparaison de deux méthodes de détermination des teneurs en carbone organique, en azote total et du rapport $\mathrm{C} / \mathrm{N}$ de divers amendements organiques et engrais de ferme, (2004). Agrosol. 15: 107-110 ;

[32] Embi Feline Laurenza Assemien. Impact de pratiques agricoles conventionnelles et innovantes sur la fertilité des sols et les acteurs microbiens impliqués dans la zone de savanes humides de Côte d'Ivoire. Biochimie, 2018 [q-bio.BM]. Université de Lyon, Français. ffNNT : 2018LYSE1103ff. fftel-01896147;

[33] Kravchenko A. N. and Bullock D. G., - Corrélation of corn and soybean grain yield with topography and soil properties. Agronomy Journal, 2000. 92 (1), 75-83 ;

[34] Kaspar T. C., Colvin T. S., Jaynes D. B., Karlen D. L., James D. E., Meek D. W. and Butler H., 2003 - Relationship between six years of corn yields and terrain attributes. Precision Agriculture, 4 (1), 87-101 ;

[35] Blanchard M., Coulibaly K., Bognini S., Dugué, P. et Vall, É., Diversité de la qualité des engrais organiques produits par les paysans d'Afrique de l'Ouest : quelles conséquences sur les recommandations de fumure ? Biotechnologie, Agronomie, Société et Environnement, 2014. 18 (4), 512-523;

Hassimiou Halidou Djabri: Ph.D student in Agronomics Sciences option: Agroecology. Master in climate change and resilience, bachelor in Bidiversity and environment management. Author of five scientifics articles and 1 book.

Abdou Maman Mansour, Ph.D in Agronomics Sciences, option: Agropedology; Assistant Professor of Cames Universities. Author and co-author of about ten publications in the field of pedology and agro-pedology

Alzouma Mayaki Zoubeirou, full professor in soil microbiology. Director of several theses in agricultural and environmental sciences. Author and co-author of about fifteen publications in the field of pedology, agro-pedology, agroecology, agroforestry, food security and nutrition. 